\title{
Pengembangan Dongeng Antik (Anti Kekerasan) Sebagai Upaya Mengenalkan Nilai-Nilai Moral bagi Anak Usia Dini
}

\author{
Gaharani Saraswati ${ }^{1}$, Ajeng Sri Hikmayani ${ }^{2}$, Dedi $\operatorname{Irawan}^{3}$ \\ ${ }^{1}$ STKIP Sebelas April \\ Email: gaharani03@gmail.com \\ ${ }^{2}$ STKIP Sebelas April \\ Email: ajeng.childhood@gmail.com \\ ${ }^{3}$ STKIP Sebelas April \\ Email: dedi_irawan@stkip11april.ac.id@unesa.ac.id
}

\begin{tabular}{|c|c|}
\hline Kata Kunci & Abstrak \\
\hline $\begin{array}{l}\text { Dongeng, } \\
\text { kekerasa, anak } \\
\text { usia dini }\end{array}$ & $\begin{array}{l}\text { Melalui penelitian ini, peneliti mengembangkan sebuah buku dongeng Anti } \\
\text { Kekerasan (Antik) untuk mengenalkan nilai-nilai moral kepada anak. Buku } \\
\text { Dongeng Antik merupakan sebuah buku berbentuk pop-up berisi teladan bagi } \\
\text { anak. Buku ini dikembangkan dalam penelitian ini adalah buku Dongeng } \\
\text { Antik seri kekerasan fisik dengan judul "Sayang Teman". Nilai-nilai moral } \\
\text { yang dikenalkan dalam buku Dongeng Antik "Sayang Teman" ini yaitu } \\
\text { berkaitan dengan perilaku buruk dan baik. Perilaku buruk dalam buku } \\
\text { Dongeng Antik ini digambarkan ke dalam beberapa bentuk kekerasan fisik } \\
\text { seperti memukul, menendang, dan mendorong teman. Perilaku baik } \\
\text { digambarkan melalui tindakan melerai teman yang berkelahi, mengakui } \\
\text { kesalahan, dan meminta maaf. Tujuan penelitian ini antara lain menghasilkan } \\
\text { buku Dongeng Antik untuk mengenalkan nilai-nilai moral anak usia dini, } \\
\text { mengetahui kelayakan buku Dongeng Antik untuk mengenalkan nilai-nilai moral } \\
\text { anak usia dini, dan mengetahui keefektifan buku Dongeng Antik untuk } \\
\text { mengenalkan nilai-nilai moral anak usia dini. Metode yang digunakan dalam } \\
\text { penelitian ini ialah penelitian dan pengembangan (research and } \\
\text { development). Penelitian ini dilaksanakan dalam empat tahap yaitu define, } \\
\text { design, development, dan dissemination. Subjek penelitian ini adalah siswa } \\
\text { TK kelompok B di kabupaten Sumedang. Analisis data kombinasi dengan } \\
\text { tipe Convergent Parallel Mixed Methods digunakan untuk mengetahui } \\
\text { keefektifan Dongeng Antik dalam mengembangkan nilai-nilai moral anak } \\
\text { usia dini. Berdasarkan hasil ujicoba lapangan, efektivitas Dongeng Antik } \\
\text { "Sayang Teman" adalah sebesar 0,74 termasuk ke dalam kategori tinggi. Peneliti } \\
\text { merekomendasikan kepada guru dan orang tua agar mau menjadi pendengar dan } \\
\text { teman yang baik bagi anak-anak, sehingga mereka lebih terbuka dan merasa } \\
\text { dihargai. }\end{array}$ \\
\hline Keywords: & Abstract \\
\hline $\begin{array}{l}\text { Fairy tales, } \\
\text { violence, early } \\
\text { childhood }\end{array}$ & $\begin{array}{l}\text { Through this research, researchers developed an Anti Kekerasan (Antik) fairy tale } \\
\text { book to introduce moral values to children. Antik fairy tale book is a pop-up book } \\
\text { containing model for children. The book developed in this study is the Antik fairy } \\
\text { tale series of phisical violence with the title "Sayang Teman". Moral values } \\
\text { introduced in the book Antik "Sayang Teman" is related to bad and good } \\
\text { behavior. Bad behavior in the Antik fairy tale book is illustrated into several } \\
\text { forms of physical violenve such as hitting, kicking, and encouraging friends. Good } \\
\text { behavior is described through the act of breaking up a friend who is fighting, } \\
\text { admitting, a mistake and apologizing. The objectives of this research include } \\
\text { producing Antik fairy tales books to introduce moral values of early childhood, } \\
\text { knowing the feasibility of Antik fairy tales books to introduce moral values of } \\
\text { early childhood, and knowing the effectiveness of Antik fairy tales books to }\end{array}$ \\
\hline
\end{tabular}


introduce moral values of early childhood. The method used in this research is research and development. This research was carried out in four stages namely define, design, development, and dissemination. The subjects of this study were group B kindergarten students in sumedang district. Based on the results of field trials, the effectiveness of the Antik"Sayang Teman" fairy tale is 0.74 included in high category. Based on the results of field trials, the effectiveness of the Antik"Sayang Teman" fairy tale is 0.74 included in high category. The researcher recommendeds that teachers and parents want to be good listeners and friends to children, so they are more open and feel valued.

Submission: April 17, 2020. Revised: June 23, 2020. Accepted: June 30, 2020

\section{A. Pendahuluan}

Kekerasan menjadi kasus yang mengkhawatirkan bagi bangsa Indonesia, kasus kekerasan masih sering terjadi di beberapa daerah di Indonesia. Menurut Safitri (2019) Komisi Perlindungan Anak Indonesia (KPAI) mencatat banyak terjadi tindak kekerasan pada anak di Indonesia. Tahun 2019, mereka telah menerima 1.192 laporan terkait kekerasan yang dialami anak di bawah umur, (https://jabar.idntimes.com). Fakta tersebut membuktikan bahwa di tahun 2019 masih banyak terjadi kasus kekerasan terhadap anak. Hal tersebut menunjukkan bahwa dampak negatif dari kekerasan pada kasus sebelumnya tidak membuat orang jera untuk melakukan kejahatan yang sama. Lebih meresahkan lagi jika kita pahami bahwa maraknya perilaku kekerasan menggambarkan semakin banyak pula orang yang minim empatinya. Menurut Fitriyah (2019), perilaku agresif memiliki kaitan yang erat dengan kecemasan dan empati, terlebih anak-anak yang mengalami empati yang rendah, maka sangat relevan untuk merefleksikannya dalam tindakan kekerasan. Ketika seseorang memiliki empati tinggi, maka perilaku agresifnya rendah, sehingga empati merupakan variabel kunci dalam merumuskan solusi atas permasalahan perilaku agresif pada anak-anak. Untuk itu, kita perlu waspada agar kekerasan tidak terjadi lagi, khususnya pada anak.

Kekerasan terjadi pada setiap level usia perkembangan manusia baik terjadi pada anakanak, remaja, dan orang dewasa (Fitriyah, 2017, 2019; Fitriyah \& Purwoko, 2018; Purwoko \& Fitriyah, 2018). Kasus kekerasan seringkali terjadi di lingkungan terdekat anak, seperti keluarga, masyarakat dan sekolah. Menurut Habsy, dkk (2019) tekanan yang dirasakan anak selama menjalani pendidikan di Sekolah didasari adanya pembentukan berbagai komunitas atau kelompok sebagai tempat untuk mengemukakan tekanan dalam bentuk kekerasan secara verbal dan fisik. Sugijokanto (2014) mengatakan bahwa umumnya pelaku kekerasan terhadap anak adalah orang terdekat atau orang yang sudah dikenal. Kasus kekerasan sering melibatkan anak sebagai korban atau bahkan pelakunya, tentunya akan membawa dampak negatif bagi pertumbuhan dan perkembangannya. Jenis kekerasan anak antara lain: Kekerasan fisik, pengabaian anak, kekerasan seksual, dan kekerasan emosi, (Santrock, 2011). Sama halnya dengan pernyataan di atas, Abbasi dkk (2015) mengatakan bahwa di Amerika Serikat, Pusat Pengendalian dan Pencegahan Penyakit (CDC) dan Departemen Anak-Anak dan Keluarga (DCF) mendefinisikan penganiayaan anak sebagai tindakan atau serangkaian tindakan komisi atau kelalaian oleh orang tua atau pengasuh lain yang mengakibatkan bahaya, potensi untuk bahaya, atau ancaman bahaya bagi seorang anak. Kekerasan anak dapat terjadi di rumah orang tua, atau di organisasi, sekolah atau komunitas tempat anak berinteraksi. Ada empat kategori utama kekerasan anak, yaitu: Penelantaran, kekerasan fisik, kekerasan psikologis atau emosional, dan pelecehan seksual. Kekerasan fisik rentan terjadi pada anak, karena anak belum mampu melawan atau menghindarinya. Kekerasan 
fisik mempunyai dampak negatif bagi perkembangan anak, bahkan berujung kematian. Menurut Abbasi dkk (2015), sebagian besar negara dengan undang-undang kekerasan anak menganggap bahwa kecelakaan yang serius, atau tindakan yang menempatkan anak pada risiko cedera serius atau kematian, adalah ilegal. Memar, goresan, luka bakar, patah tulang, laserasi, serta "kecelakaan" berulang-ulang, dan perlakuan kasar yang bisa menyebabkan cedera fisik, bisa berupa kekerasan fisik.

Berdasarkan wawancara dengan orang tua (tanggal 18 Mei 2019) siswa di TK "X", anakanak tanpa disadari sering menjadi korban pelampiasan kekesalan ayah atau ibunya ketika mengalami masalah, terutama ketika anak rewel. Anak yang sulit diatur ketika sedang rewel rentan untuk mendapatkan perlakuan kasar dan kadang-kadang berujung pada tindakan kekerasan. Anak-anak juga kadang-kadang tanpa sadar melakukan kekerasan kepada teman dan orang tuanya ketika merasa kesal atau keinginannya tidak terpenuhi. Namun, hal tersebut karena ia belum mengerti. Abbasi dkk (2015) mengatakan penting untuk menekankan bahwa anak-anak adalah korban dan tidak boleh disalahkan atas penganiayaan. Sejumlah karakteristik seorang anak dapat meningkatkan kemungkinan dianiaya, antara lain: Berusia di bawah empat tahun atau remaja, tidak diinginkan, atau gagal memenuhi harapan orang tua, dan memiliki kebutuhan khusus, terus-menerus menangis atau memiliki fitur fisik yang abnormal.

Melihat pernyataan tersebut, maka peneliti dalam hal ini bermaksud mencegah kekerasan fisik melalui pendidikan dengan mengajak anak untuk berpartisipasi. Hal ini mendorong mereka untuk mampu mengekspresikan pendapatnya, sehingga dapat memberdayakan hak mereka untuk hidup dengan layak. Menurut Lansdown (2011), hak untuk mengekspresikan pandangan dan menganggapnya serius adalah alat yang kuat untuk menantang situasi kekerasan, pelecehan, ancaman, ketidakadilan atau diskriminasi. Dalam hal ini, orang tua dan orang dewasa lainnya seharusnya mau menjadi pendengar yang baik anak. Selain itu, agar anak terhindar dari perilaku kekerasan diperlukan langkah untuk mengembangkan wawasan mereka, yaitu melalui pengenalan nilai-nilai moral anak. Dengan mengenalkan nilai-nilai moral, anak akan memahami bahwa kekerasan adalah perilaku yang tidak patut ditiru dan menyalahi norma. Kekerasan merupakan salah satu bentuk perilaku menyimpang, (Sarlito dalam Yuniati dkk, 2017). Moral diartikan sebagai peraturan, nilai-nilai dan prinsip moral, kesadaran orang untuk menerima dan melakukan peraturan, nilai-nilai, dan prinsip yang telah baku dan dianggap benar (Susanto, 2014). Kohlberg dalam Mursid (2015) mengemukakan bahwa, aspek moral adalah sesuatu yang tidak dibawa dari lahir, tetapi sesuatu yang berkembang dan dapat dipelajari. Perkembangan moral merupakan proses internalisasi nilai atau norma masyarakat sesuai dengan kematangan seseorang dalam menyesuaikan diri terhadap aturan yang berlaku dalam kehidupannya. Jadi, perkembangan moral mencakup aspek kognitif yaitu pengetahuan tentang baik atau buruk dan benar atau salah, serta faktor afektif berupa sikap atau moral tersebut dipraktikkan. Dengan mengajarkan nilai-nilai moral, anak akan belajar melalui pembiasaan tentang aturan dan mengetahui sikap yang harus dilakukan pada orang lain saat berinteraksi. Mengajarkan nilai-nilai moral sejak usia dini akan menjadi dasar pembentukan karakter anak. Sesmiarni (2019) mengatakan bahwa pendidikan moral pada anak usia dini adalah salah satu upaya untuk mempersiapkan kehidupan untuk masa depan sebagai dasar pembentukan karakteristik anak. Menurut Lickona (dalam Ananda, 2017) pembentukan karakter anak dapat dilakukan melalui tiga kerangka pikir, yaitu konsep moral (moral knowing), sikap moral (moral feeling), dan perilaku moral (moral behavior).

Pembelajaran moral di sekolah biasanya terjadi pada saat proses pembelajaran sehari-hari. Ketika anak-anak sedang bermain bersama teman, di sana mereka secara tidak langsung mengalami proses pembelajaran moral. Misalnya belajar berbagi, bersabar, dan lain-lain. Anak- 
anak juga belajar bahwa mengganggu temannya adalah hal yang seharusnya tidak dilakukan, karena hal tersebut dapat membuat temannya marah dan sedih. Selain itu, dongeng adalah salah satu cara yang cukup ampuh untuk mengenal baik dan buruk. Anak lebih mudah mengerti jika guru menceritakan sebuah dongeng. Mereka terlihat sangat antusias dan memetik pelajaran dari peristiwa di dalam dongeng (Wawancara tanggal 22 Mei 2019). Berdasarkan pengalaman guru tersebut, pendidikan moral berlangsung ketika pembelajaran sehari-hari dan dongeng sangat membantu guru dalam mengajarkan nilai-nilai moral kepada anak. Namun, pembelajaran moral tidak secara spesifik mencegah kekerasan di sekolah. Melihat urgensi pendidikan moral bagi anak dan manfaat dongeng, maka peneliti mengembangkan sebuah buku dongeng sebagai media untuk mencegah kekerasan.

Rahim dan Rahiem (2012) mengatakan, dongeng diakui memiliki potensi untuk berkontribusi secara signifikan pada pendidikan moral anak-anak dan orang dewasa. Dongeng efektif dalam memberikan teladan, peluang untuk membahas dilema moral, dan memiliki potensi untuk berkontribusi secara signifikan pada pendidikan moral anak-anak dan orang dewasa. Pada usia dini, anak membutuhkan gambaran secara konkrit untuk mengenalkan situasi tertentu, sehingga dijadikan pedoman dalam berperilaku. Dongeng menjadi salah satu alternatif untuk memberikan gambaran konkrit. Selain itu, usia 4-6 tahun adalah usia anak menyukai dongeng, karena memiliki daya imajinasi pada alur cerita dan gambar yang menggambarkan situasi alur cerita. Berkaitan dengan alur cerita, maka melalui dongeng dapat disisipkan pesanpesan moral, sehingga diharapkan anak akan mudah menerima pesan yang terkandung di dalamnya. Menurut Horn (dalam Ahyani 2010) dongeng mempunyai kemampuan untuk menciptakan lingkungan belajar yang benar untuk siswa usia dini. Selain itu, dongeng dapat dijadikan sebagai media membentuk kepribadian dan moralitas anak usia dini. Collin (dalam Ahyani, 2010) mengatakan bahwa dongeng mempunyai banyak kegunaan di dalam pendidikan terutama anak usia dini. Dongeng menstimulasi terbentuknya kerangka konseptual untuk berpikir, sehingga membentuk pengalaman menjadi keseluruhan yang dapat dipahami oleh anak. Dongeng membentuk mental pengalaman anak karena melihat gambaran melalui alur cerita yang disajikan dalam dongeng.

Adapun dongeng yang dikembangkan dalam penelitian ini adalah Dongeng Antik (Anti Kekerasan). Dongeng Antik menyajikan sebuah pengalaman melalui peristiwa yang tergambar di dalamnya. Anak-anak belajar tentang perilaku buruk yang digambarkan dalam bentuk kekerasan, sehingga tidak boleh dilakukan. Mereka juga akan dikenalkan dengan beberapa sikap yang harus dilakukan jika melihat atau melakukan tindakan kekerasan. Buku didesain dalam bentuk pop-up, hal ini mempermudah anak dalam memahami pesan-pesan moral yang terkandung di dalamnya. Dengan demikian, anak dapat menerapkan nilai-nilai di dalam dongeng ke dalam kehidupan sehari-hari. Dongeng Antik juga mengajak orang dewasa di sekitar anak, khususnya orang tua dan guru untuk tidak menghakimi dan mau mendengarkan mereka. Sama halnya dengan pendapat Al-Somadi (2012) bahwa, buku dongeng yang bermakna untuk anak-anak dapat menyajikan pengalaman yang memiliki koneksi dengan kehidupan mereka. Jadi, literatur dapat membantu anak-anak belajar tentang dunia nyata dengan cara menyenangkan dan menarik, memahami lingkungan mereka, dan memahami hubungan dengan orang lain. Dengan kata lain, literatur anak-anak memberi anak-anak jawaban mendasar tentang siapa mereka, bagaimana mereka harus hidup di dunia mereka, dan bagaimana mereka hidup satu sama lain.

Dongeng Antik melibatkan beberapa aktivitas penggunanya yaitu aktivitas membaca dan bercerita. Membaca merupakan bentuk stimulasi literasi awal pada anak, sedangkan bercerita memberikan sentuhan manusiawi (human touch) yang menstimulasi ungkapan hati anak yang 
Gaharani Saraswati, Ajeng Sri Hikmayani, Dedi Irawan

Pengembangan Dongeng Antik (Anti Kekerasan) Sebagai Upaya Mengenalkan Nilai-Nilai Moral baai Anak Usia Dini

berbentuk reseptif dan ekspresif. Anak akan menyimak gambaran peristiwa dalam dongeng dan akan menstimulasi mereka untuk mengekspresikannya dalam kehidupan nyata. Sanchez dalam Ahyani (2010) mengungkapkan bahwa kekuatan utama strategi dongeng adalah menghubungkan rangsangan melalui penggambaran karakter. Dongeng memiliki potensi untuk memperkuat imajinasi, memanusiakan individu, meningkatkan empati dan pemahaman, memperkuat nilai dan etika, dan merangsang proses pemikiran kritis dan kreatif. Melalui pengembangan Dongeng Antik diharapkan mendorong anak agar tidak melakukan tindak kekerasan di kemudian hari. Mencegah kekerasan pada anak adalah upaya untuk memberdayakan hak mereka untuk hidup.

\section{B. Metodologi}

Penelitian tentang Pengembangan Dongeng Antik (Anti Kekerasan) sebagai Upaya Mengenalkan Nilai-Nilai Moral bagi Anak Usia Dini ini menggunakan metode penelitian dan pengembangan atau dikenal dengan research and development $(R \& D)$. Penelitian ini bertujuan menghasilkan produk baru berupa buku Dongeng Antik dan mengetahui kelayakan serta efektifitasnya dalam mengenalkan nilai-nilai moral pada anak usia dini. Penelitian dan pengembangan ini menggunakan model dari Thiagarajan. Menurut Sugiyono (2015), model ini memiliki empat langkah, yaitu:: Pertama, Define (pendefinisian) berisi kegiatan untuk menetapkan produk apa yang akan dikembangkan, beserta spesifikasinya. Tahap ini merupakan kegiatan analisis kebutuhan, yang dilakukan melalui penelitian dan studi literatur. Pada tahap ini, peneliti mengumpulkan referensi, menyusun materi dan alur cerita, serta menyusun indikator penilaian. Kedua Design (perancangan), berisi kegiatan untuk membuat rancangan terhadap produk yang telah ditetapkan, meliputi penyusunan cerita, desain gambar, menyesuaikan indikator penilaian dengan cerita dan gambar. Ketiga Development (pengembangan), berisi kegiatan membuat rancangan menjadi produk dan menguji validitas produk secara berulang-ulang sampai dihasilkan produk yang sesuai dengan spesifikasi yang ditetapkan, meliputi pembuatan buku dongeng berbentuk pop-up, validasi dan revisi, uji coba terbatas, uji coba lapangan. Keempat Dissemination (diseminasi), berisi kegiatan menyebarluaskan produk yang telah teruji untuk dimanfaatkan orang lain yaitu melalui sosialisasi dongeng antik kepada orang tua dan para guru, serta seminar hasil. Tahap penelitian dan pengembangan ini dapat digambarkan sebagai berikut.

\begin{tabular}{|c|c|c|c|c|}
\hline 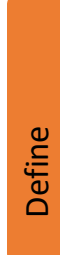 & $\begin{array}{l}\text { Mengumpulkan } \\
\text { referensi } \\
\text { Menyusun materi dan } \\
\text { alur cerita } \\
\text { Menyusun indikator } \\
\text { penilaian }\end{array}$ & $\begin{array}{ll} & \text { Menyusun Cerita } \\
& \text { Desain gambar } \\
& \text { Menyesuaikan } \\
\frac{.00}{\sqrt[0]{\nu}} & \text { indikator penilaian } \\
\stackrel{0}{0} \text { dengan cerita dan } \\
\text { gambar }\end{array}$ & 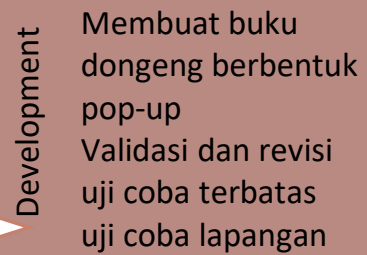 & 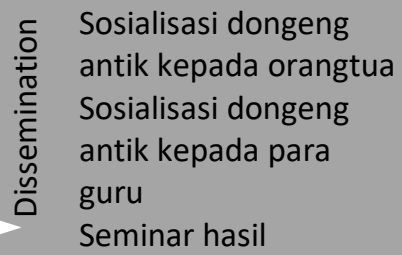 \\
\hline
\end{tabular}

Gambar 2.1 Tahap Penelitian

Subjek dalam penelitian ini adalah siswa kelompok B TK "X" di Kabupaten Sumedang. Peneliti memilih kelompok B sebagai subjek penelitian dengan alasan siswa telah memasuki tahun ke dua di sekolah, sehingga guru dan peneliti lebih mudah mengarahkan dan membimbing siswa dalam proses penelitian. Selain itu, siswa-siswa kelompok B telah mampu mendeskripsikan pendapatnya. Hal ini sesuai dengan kebutuhan penelitian yang mengharuskan anak mampu berpendapat tentang beberapa peristiwa dalam dongeng. Uji coba terbatas 
melibatkan seorang guru dan dua siswa kelas B3 TK "X", sedangkan uji coba operasional dilaksanakan melibatkan seluruh siswa kelompok B1 TK "X".

Instrumen penelitian ini menggunakan lembar observasi angket untuk validasi ahli media dan materi, lembar tes, dan pedoman wawancara. Data yang dibutuhkan dalam penelitian dan pengembangan ini berupa data kualitatatif dan kuantitatif. Untuk memperoleh data kualitatif, maka teknik pengumpulan data wawancara, observasi, dan dokumentasi, sedangkan untuk memperoleh data kuantitatif, peneliti menggunakan teknik pengumpulan data berupa tes dan angket.

Teknik analisis data kelayakan buku Dongeng Antik dilakukan dengan mentabulasi semua data yang diperoleh dari validator untuk setiap indikator, dan subindikator dari butir penilaian yang tersedia dalam instrumen penilaian. Langkah selanjutnya menghitung skor total rata-rata setiap komponen indikator. Data berupa skor penilaian ahli materi, ahli media, dan respon guru. Kemudian, langkah selanjutnya mengubah rata-rata menjadi nilai dengan kriteria yang dikonversikan. Data yang dikonversikan mengacu pada rumus yang dikemukakan oleh (Sukardjo, 2005), rumus tersebut dapat dilihat pada tabel 1 berikut:

Tabel 1 Konversi Skor Aktual Menjadi Sikap Lima

\begin{tabular}{|l|l|l|}
\hline Data Kuantitatif & Rentang & Data Kualitatif \\
\hline 5 & $\mathrm{X}>\mathrm{Xi}+1,80 \mathrm{Sbi}$ & Sangat Baik \\
\hline 4 & $\mathrm{Xi}+0,60 \mathrm{Sbi}<\mathrm{X}>\mathrm{Xi}+1,80 \mathrm{Sbi}$ & Baik \\
\hline 3 & $\mathrm{Xi}-0,60 \mathrm{Sbi}<\mathrm{X}>\mathrm{Xi}+0,60 \mathrm{Sbi}$ & Cukup \\
\hline 2 & $\mathrm{Xi}-1,80 \mathrm{Sbi}<\mathrm{X}>\mathrm{Xi}-0,60 \mathrm{Sbi}$ & Kurang \\
\hline 1 & $\mathrm{X} \leq \mathrm{Xi}-1,80 \mathrm{Sbi}$ & Sangat Kurang \\
\hline
\end{tabular}

Keterangan:

$\begin{array}{rll}\mathrm{Xi} & = & \text { Rerata ideal } \\ & =1 / 2(\text { skor mak }+ \text { skor min }) \\ \mathrm{Sbi} & = & \text { Simpang baku ideal } \\ & =1 / 6(\text { skor mak }- \text { skor min }) \\ \mathrm{X} & = & \text { Skor Aktual }\end{array}$

Untuk mengetahui data rerata penilaian yang akan digunakan sebagai kesimpulan, digunakan rumus berikut:

$$
\text { Keidealan }=\quad \frac{\text { Skor perolehan }}{\text { Skor maksimal }}
$$

Pedoman konversi di atas digunakan untuk menentukan kelayakan produk yang akan dikembangkan. Nilai kelayakan produk ditetapkan kriteria minimal "cukup" pada buku dongeng Antik. Artinya buku dongeng Antik hasil pengembangan layak digunakan dalam pembelajaran.

Analisis data kombinasi dengan tipe Convergent Parallel Mixed Methods digunakan untuk mengetahui keefektifan Dongeng Antik dalam mengembangkan nilai-nilai moral anak usia dini. Menurut Sugiyono (2015) pada tipe ini penelitian baik kualitatif maupun kuantitatif digunakan secara bersama-sama dalam waktu yang sama. Peneliti mengumpulkan data secara kuantitatif dan kualitatif, serta menganalisisnya. Hasil analisis analisis kuantitatif dan kualitatif selanjutnya dibandingkan dan diberi interpretasi. Creswell (Sugiyono, 2015) menyatakan bahwa dalam pendekatan ini, peneliti dalam waktu yang sama mengumpulkan data kuantitatif dan kualitatif, menganalisis data secara terpisah, dan membandingkan hasilnya untuk mengetahui apakan temuannya itu saling melengkapi atau tidak. Asumsi dalam pendekatan ini adalah dengan menggunakan dua metode akan 
diperoleh data yang berbeda, tetapi dapat saling melengkapi, memperkuat, memperdalam, saling bertentangan dan ada temuan baru.

\section{Hasil dan Pembahasan}

Berdasarkan studi pendahuluan, diperoleh gambaran bahwa setiap guru di TK " $\mathrm{X}$ " merasa bahwa membaca dongeng merupakan hal yang penting bagi anak. Hal itu disebabkan karena dengan mendongeng dapat menambah pengalaman anak dengan cara menggambarkan atau memberi contoh tentang nilai-nilai kehidupan, termasuk tentang kekerasan. Jenis kekerasan yang dipilih dalam penelitian ini adalah kekerasan fisik. Hal ini didasari oleh fakta yang menunjukkan bahwa seringnya jenis kekerasan ini terjadi di sekolah, baik disadari maupun tidak. Menurut sejumlah guru kekerasan yang sering dilakukan oleh orang tua tanpa mereka sadari, misalnya mencubit anak ketika tidak mau masuk kelas atau rewel. Kekerasan juga sering dilakukan oleh anak terhadap temannya, misalnya memukul, mendorong, dan menendang. Namun, pada dasarnya anak tidak memiliki maksud jahat dalam berperilaku. Mengacu pada teori Kohlberg (Soetjiningsih, 2014) anak-anak usia prasekolah yang penalaran kognitifnya ada pada tahap praoperasional, perkembangan moralnya juga masih terbatas. Anak belum memahami bahwa tindakan kekerasan yang dilakukan benar atau salah. Kekerasan yang dilakukan anak memiliki alasan tertentu, misalnya karena merasa terganggu, tidak suka, tidak nyaman, ataupun ingin diperhatikan oleh orang lain. Hal tersebut terjadi karena anak belum mengerti sepenuhnya tentang konsep moral. Meskipun demikian, kekerasan tidak boleh dibiarkan berlarut-larut dan harus segera dicegah agar tidak terjadi efek negatif.

Margaret dkk (dalam Saputri dan Astuti 2019) mengatakan bahwa paparan kekerasan pada anak-anak dapat menyebabkan berbagai masalah dalam jangka pendek dan panjang. Soetjiningsih (dalam Saputri dan Astuti 2019) menambahkan, efek jangka pendek yang akan dialami anak-anak ketika seorang anak mengalami kekerasan fisik dapat menyebabkan kematian, patah tulang atau cedera, dan pertumbuhan fisik yang berbeda dari teman sebaya. Soetjiningsih (dalam Saputri dan Astuti 2019) juga menyebutkan bahwa efek jangka panjang yang dapat dialami oleh anak-anak yang menjadi korban kekerasan adalah perasaan malu atau menyalahkan diri sendiri, kecemasan atau depresi, kehilangan minat di sekolah, stres pasca trauma, seperti terus-menerus memikirkan peristiwa traumatis, dan juga dapat tumbuh sebagai anak yang mengisolasi dirinya dari lingkungan sekitarnya.

\section{Hasil Validasi Ahli Materi}

Validasi dilakukan dengan dua kali revisi pada komponen materi berupa penyajian cerita, ilustrasi Pop-Up, bentuk fisik buku, dan cover. Berdasarkan analisa dan evaluasi oleh ahli materi pada tahap kedua hasil yang telah diperbaiki di antaranya: 1) Panduan untuk guru sudah teralur baik; 2)Semua gambar terlihat originalitas; 3) Gambaran penilaian moral sudah spesifik; 4) Ilustrasi cerita sudah memberikan pesan moral.

Berdasarkan hasil pengembangan media yang kedua tersebut maka dapat disimpulkan dengan penilaian hasil dari validasi ahli materi. Hasil tersebut dapat dijelaskan pada tabel 2 berikut ini.

Tabel 2. Indikator Penyajian Cerita

\begin{tabular}{|c|l|c|}
\hline No & \multicolumn{1}{|c|}{ Indikator } & Skor \\
\hline 1 & $\begin{array}{l}\text { Menggambarkan kesesuaian cerita dengan } \\
\text { tahapan usia perkembangan anak }\end{array}$ & 4 \\
\hline 2 & Alur cerita yang digunakan menujukan kelogisan & 4 \\
\hline
\end{tabular}




\begin{tabular}{|c|l|c|}
\hline 3 & $\begin{array}{l}\text { Tokoh cerita menunjukan kesesuaian dengan alur } \\
\text { dan tema }\end{array}$ & 4 \\
\hline 4 & $\begin{array}{l}\text { Latar penceritaan menggambarkan kesesuaian } \\
\text { dengan alur dan tema }\end{array}$ & 4 \\
\hline 5 & $\begin{array}{l}\text { Cerita disusun secara naratif, sistematis, dan } \\
\text { logis. }\end{array}$ & 4 \\
\hline 6 & $\begin{array}{l}\text { Menggunakan gaya tulis dialogis dan komunikatif } \\
\text { (mudah dicerna) }\end{array}$ & 4 \\
\hline 7 & $\begin{array}{l}\text { Menggunakan bahasa Indonesia baik dan benar } \\
\text { serta mudah dipahami }\end{array}$ & 4 \\
\hline 8 & $\begin{array}{l}\text { Menarik dan merangsang rasa ingin tahu } \\
\text { positif dan larangan nilai negatif }\end{array}$ & 5 \\
\hline 9 & $\begin{array}{l}\text { Cerita bersifat menegaskan penanaman nilai } \\
\text { kemiliki kandungan nilai-nilai karakter } \\
10\end{array}$ & $\begin{array}{l}\text { Kumlah Skor } \\
\text { Kritan - Rata }\end{array}$ \\
\hline
\end{tabular}

Perhitungan pada tabel 2 menunjukan skor rata-rata 4,1, sehingga dapat diartikan masuk pada kriteria sangat baik berdasarkan tabel konversi. Hasil didapatkan dari masing-masing indikator memiliki jumlah 41 dari 10 butir pertanyaan. Untuk melihat hasil indikator ilustrasi pop-up dapat dilihat pada tabel 3 berikut ini.

Tabel 3. Indikator Ilustrasi Pop-Up

\begin{tabular}{|c|l|c|}
\hline No & \multicolumn{1}{|c|}{ Indikator } & Skor \\
\hline 1 & $\begin{array}{l}\text { Menunjukan kecukupan ilustrasi (berupa benda, } \\
\text { tokoh, pengalaman, dsb.) sesuai dengan } \\
\text { kontekstual yang mewakili konsep untuk } \\
\text { memantapkan anak dalam memahami cerita }\end{array}$ & 4 \\
\hline 2 & $\begin{array}{l}\text { Gambaran tokoh tidak menyalahi SARA dan } \\
\text { sesuai dengan logika anak }\end{array}$ & 5 \\
\hline 3 & $\begin{array}{l}\text { Ilustrasi menggambarkan seluruh alur dalam } \\
\text { cerita }\end{array}$ & 5 \\
\hline 4 & $\begin{array}{l}\text { Ilustrasi memiliki pewarnaan yang logis dan } \\
\text { kontekstual }\end{array}$ & $\mathbf{1 9}$ \\
\hline & Jumlah Skor & $\mathbf{4 , 7 5}$ \\
\hline & Rata-rata & Sangat Baik \\
\hline
\end{tabular}

Perhitungan pada tabel 3 diperoleh dari masing-masing indikator ketepatan media dalam pengguna, bentuk media, dan pemilihan bahan memiliki jumlah 19 dari 4 butir pertanyaan dengan rata-rata 4,75, sehingga jika dilihat dari tabel konversi skor mendapat kriteria sangat baik.

\section{Hasil Validasi Ahli Media}

Validasi dilakukan dengan dua kali revisi pada komponen materi berupa bentuk fisik, cover, penyajian cerita, ilustrasi pop-up. Adapun analisa dan evaluasi oleh ahli media pada tahap kedua hasil yang telah diperbaiki di antaranya: 1) Ukuran buku sudah sesuai dengan kebutuhan anak; 2) Kesesuaian gambar dengan alur cerita; 3) Ukuran gambar dan warna pada gambar sudah baik. 
Gaharani Saraswati, Ajeng Sri Hikmayani, Dedi Irawan

Pengembangan Dongeng Antik (Anti Kekerasan) Sebagai Upaya Mengenalkan Nilai-Nilai

Moral baai Anak Usia Dini

Hasil dari ahli media dapat disimpulkan penilaian hasil dari validasi ahli media. Hasil tersebut dapat dijelaskan pada tabel 4 berikut ini:

Tabel 4 Indikator Bentuk Fisik Buku

\begin{tabular}{|c|l|c|}
\hline No & \multicolumn{1}{|c|}{ Indikator } & Skor \\
\hline 1 & Ukuran & 5 \\
\hline 2 & Bentuk buku & 5 \\
\hline 3 & Jenis huruf & 4 \\
\hline 4 & Ukuran huruf $\quad$ Rumlah Skor & 4 \\
\hline \multicolumn{2}{c|}{ Kriteria } & $\mathbf{1 8}$ \\
\hline \multicolumn{2}{c}{ S,5 } \\
\hline
\end{tabular}

Perhitungan pada tabel 4, bahwa skor yang didapatkan pada keterbacaan media yang diperoleh dari masing-masing indikator keterbacaan kalimat dan kejelasan gambar memiliki jumlah skor 18 dari butir pertanyaan dengan rata-rata 4,5, sehingga jika dilihat dari tabel konversi, maka skor mendapat kriteria sangat baik. Kriteria indikator cover dapat dilihat pada tabel 5 beikut:

Tabel 5 Indikator Ketepatan Media dengan Tujuan

\begin{tabular}{|c|l|c|}
\hline No & Indikator & Skor \\
\hline 1 & Terdapat identitas & 5 \\
\hline 2 & Kesesuaian dengan isi buku & 5 \\
\hline 3 & Tampilan cover & 5 \\
\hline \multicolumn{2}{c}{ Jumlah Skor } & $\mathbf{1 5}$ \\
\hline Rata-rata & $\mathbf{5}$ \\
\hline Kriteria & Sangat Baik \\
\hline
\end{tabular}

Perhitungan pada tabel 5 menunjukkan bahwa skor dari masing-masing indikator kesesuaian tujuan, dan kejelasan rumusan materi memiliki 3 pertanyaan dengan rata-rata 5, sehingga jika dilihat dari tabel konversi, maka skor mendapat kriteria sangat baik. Kriteria indikator penyajian cerita dapat dilihat pada tabel 6 berikut:

Tabel 6 Indikator Penyajian Cerita

\begin{tabular}{|c|l|c|}
\hline No & \multicolumn{1}{|c|}{ Indikator } & Skor \\
\hline 1 & $\begin{array}{l}\text { Menggambarkan kesesuaian cerita dengan tahapan } \\
\text { usia perkembangan anak }\end{array}$ & 3 \\
\hline 2 & Alur cerita yang digunakan menujukan kelogisan & 4 \\
\hline 3 & $\begin{array}{l}\text { Tokoh cerita menunjukan kesesuaian dengan alur dan } \\
\text { tema }\end{array}$ & 5 \\
\hline 4 & $\begin{array}{l}\text { Latar penceritaan menggambarkan kesesuaian dengan } \\
\text { alur dan tema }\end{array}$ & 4 \\
\hline 5 & $\begin{array}{l}\text { Cerita disusun secara naratif, sistematis, dan logis. } \\
\text { (mudah dicerna) }\end{array}$ & 4 \\
\hline 7 & $\begin{array}{l}\text { Menggunakan bahasa Indonesia baik dan benar serta } \\
\text { mudah dipahami }\end{array}$ & 3 \\
\hline 8 & $\begin{array}{l}\text { Menarik dan merangsang rasa ingin tahu } \\
\text { dan larangan nilai negatif }\end{array}$ & 4 \\
\hline 9 & $\begin{array}{l}\text { Cerita bersifat menegaskan penanaman nilai positif } \\
\text { anti kekerasan }\end{array}$ & 5 \\
\hline 10 & $\begin{array}{l}\text { Jumlah Skor } \\
\text { Rata - Rata }\end{array}$ \\
\hline
\end{tabular}


Perhitungan pada tabel 6 menunjukan skor rata-rata 4 sehingga jika dilihat dari Tabel konversi, maka skor mendapat kriteria sangat baik. Hasil didapatkan dari masing-masing indikator memiliki jumlah 40 dari 10 butir pertanyaan. Untuk melihat hasil indikator ilustrasi pop-up dapat dilihat pada tabel 7 berikut ini:

Tabel 7 Indikator Ilustrasi Pop-Up

\begin{tabular}{|c|l|c|}
\hline No & \multicolumn{1}{|c|}{ Indikator } & Skor \\
\hline 1 & $\begin{array}{l}\text { Menunjukan kecukupan ilustrasi (berupa benda, tokoh, } \\
\text { pengalaman, dsb.) sesuai dengan kontekstual yang } \\
\text { mewakili konsep untuk memantapkan anak dalam } \\
\text { memahami cerita }\end{array}$ & 4 \\
\hline 2 & $\begin{array}{l}\text { Gambaran tokoh tidak menyalahi SARA dan sesuai } \\
\text { dengan logika anak }\end{array}$ & 5 \\
\hline 3 & Ilustrasi menggambarkan seluruh alur dalam cerita & 5 \\
\hline 4 & Ilustrasi memiliki pewarnaan yang logis dan kontekstual & 5 \\
\hline & Jumlah & $\mathbf{1 9}$ \\
\hline & Kata-rata & $\mathbf{4 , 7 5}$ \\
\hline
\end{tabular}

Perhitungan pada tabel 7 diperoleh dari semua indikator ketepatan media dalam pengguna, bentuk media, dan pemilihan bahan memiliki jumlah 19 dari 4 butir pertanyaan dengan rata-rata 4,75, sehingga jika dilihat dari tabel konversi, maka skor mendapat kriteria baik sekali.

\section{Hasil Uji Coba Terbatas \\ Deskripsi Validasi dengan Subjek Guru}

Uji Validasi menggunakan angket melibatkan satu subjek sebagai validator buku Dongeng Antik. Adapun aspek yang dinilai meliputi kejelasan buku panduan, penyajian cerita, dan ilustrasi pop-up. Tujuannya adalah untuk memperoleh masukan untuk meningkatkan kualitas buku dongeng. Validasi dengan subjek guru dilakukan di TK "X" Sumedang. Respon yang telah diterima kemudian dianalisis dan digunakan untuk merevisi buku Dongeng Antik.

Tabel 8 Hasil Validasi Guru

\begin{tabular}{|c|c|c|}
\hline No & Indikator & Skor \\
\hline 1 & Buku panduan & 22 \\
\hline 2 & Dongeng Antik & 41 \\
\hline & Jumlah skor & $\mathbf{6 3}$ \\
\hline & Butir pertanyaan & $\mathbf{1 8}$ \\
\hline & Rata-rata & $\mathbf{3 , 5}$ \\
\hline & Kriteria & Baik \\
\hline
\end{tabular}

Hasil validasi guru pada tabel 8 menunjukkan tentang penilaian Dongeng Antik "Sayang Teman pada dua aspek penting dengan jumlah pertanyaan 18 butir. Skor total yang didapat 63 dengan rata-rata 3,5, dari. sehingga kriteria konversi skor adalah baik.

\section{Deskripsi Uji Coba Terbatas dengan Subjek Anak}

Langkah berikutnya setelah validasi dilaksanakan adalah menerapkan Dongeng Antik "Sayang Teman" pada subjek uji coba. Uji coba terbatas dilaksanakan dengan subjek empat anak. Penelitian dilaksanakan di kelompok B3 yang dipilih secara acak. Diawali dengan peneliti memberi gambaran pada guru tentang buku panduan penggunaan buku dongeng dan esensi dari Dongeng Antik "Sayang Teman". Selanjutnya, guru mendongeng sambil memainkan buku dongeng. Keempat anak memperhatikan dengan seksama. Setelah itu, guru memberikan 
beberapa pertanyaan sesuai dengan panduan. Anak-anak sangat antusias mendengarkan cerita sambil memperhatikan gambar pop-up. Mereka juga terlihat penasaran dengan halaman berikutnya.

Berdasarkan hasil uji coba terbatas, maka peneliti perlu merevisi buku Dongeng Antik "Sayang Anak". Hal-hal yang harus direvisi meliputi: 1) Mempertajam ekspresi tokoh pada gambar; 2) Ilustrasi suasana pada dongeng "Sayang Teman" harus lebih menggambarkan suasana di TK; 3) Desain pop-up dibuat lebih bervariasi agar tidak terkesan monoton dan anak lebih antusias.

\section{Hasil Uji Coba Lapangan}

Uji coba lapangan dilaksanakan di TK "X" Sumedang. Uji lapangan ini dilaksanakan di kelompok B1 dengan subjek yang berjumlah 16 anak. Uji lapangan dilakukan pada satu kelas dengan model one grup pretest dan posttest yaitu untuk mengetahui efektivitas Dongeng Antik "Sayang Anak" dalam mengenalkan nilai-nilai moral anak usia dini. Secara teknis uji coba lapangan ini berbeda dengan uji coba terbatas. Jika uji coba terbatas hanya melibatkan subjek dua anak, maka uji coba lapangan ini melibatkan 16 anak dengan kelompok usia yang sama. Pretest dilakukan untuk mengukur pemahaman awal anak tentang nilai-nilai moral anti kekerasan. Kemudian peneliti melakukan treatment dengan cara mendongeng menggunakan buku Dongeng Antik berjudul "Sayang Teman" dengan bentuk pop-up. Dikarenakan sampel terlalu sedikit yaitu hanya melibatkan 16 subjek saja, maka dari itu, analisis data penelitian menggunakan statistik nonparametrik. Untuk melihat efektivitas Dongeng Antik "Sayang Teman", maka menggunakan gain yang dinormalisasi dengan alasan ingin melihat peningkatan yang terjadi sesudah dan sebelum perlakuan dengan melihat data siswa.

Tabel 9 Kriteria Efektivitas (Richard R. Hake)

\begin{tabular}{|l|c|}
\hline Rata-rata skor gain dinormalisasi & Efektivitas \\
\hline $0,00<(\mathrm{g}) \leq 0,30$ & Rendah \\
\hline $0,30<(\mathrm{g}) \leq 0,70$ & Sedang \\
\hline $0,70<(\mathrm{g}) \leq 1,00$ & Tinggi \\
\hline
\end{tabular}

Adapun perbandingan pretest dan posttest dapat diihat dari tabel berikut.

Tabel 10 Perbandingan Hasil Pretest dan Posttest Berdasarkan Rata-Rata

\begin{tabular}{|c|c|c|c|}
\hline Subyek & Pretest & Posttest & $\langle\mathbf{g}\rangle$ \\
\hline S1 & 2,00 & 4,78 & 0,69 \\
\hline S2 & 2,44 & 4,67 & 0,63 \\
\hline S3 & 2,00 & 4,56 & 0,64 \\
\hline S4 & 2,11 & 4,44 & 0,60 \\
\hline S5 & 2,22 & 4,44 & 0,59 \\
\hline S6 & 1,00 & 3,44 & 0,49 \\
\hline S7 & 2,00 & 4,67 & 0,67 \\
\hline S8 & 2,22 & 4,56 & 0,62 \\
\hline S9 & 2,00 & 4,56 & 0,64 \\
\hline S10 & 2,00 & 4,56 & 0,64 \\
\hline S11 & 2,22 & 4,78 & 0,68 \\
\hline S12 & 1,00 & 3,33 & 0,47 \\
\hline S13 & 1,33 & 3,56 & 0,48 \\
\hline
\end{tabular}




\begin{tabular}{|c|c|c|c|}
\hline S14 & 2,00 & 4,00 & 0,50 \\
\hline S15 & 1,22 & 3,33 & 0,44 \\
\hline S16 & 1,78 & 3,33 & 0,37 \\
\hline Total & $\mathbf{1 , 8 5}$ & $\mathbf{4 , 1 9}$ & $\mathbf{0 , 7 4}$ \\
\hline
\end{tabular}

Berdasarkan data tersebut, maka efektivitas Dongeng Antik "Sayang Teman" adalah sebesar 0,74 termasuk ke dalam kategori tinggi. Salah satu faktor yang mendukung keefektifan Dongeng Antik "Sayang Teman" ini adalah bentuk pop-up pada dongeng ini mampu memberikan gambaran bagi anak tentang beberapa peristiwa di dalam cerita, sehingga anak mudah memahami maksud dari cerita tersebut. Bukan hanya itu, sebagian anak mampu memberikan contoh lain tentang peristiwa serupa berdasarkan pengalaman bermain mereka sehari-hari. Menggunakan dongeng sebagai media untuk mengenalkan nilai-nilai moral kepada anak menstimulasi mereka untuk bertanya dan mulai memikirkan apa yang akan mereka lakukan. Hal ini sesuai dengan pendapat Rahim dan Rahiem (2012) bahwa, cerita memiliki potensi yang berfungsi sebagai wahana pendidikan moral bagi anak kecil. Anak-anak belajar nilai-nilai agama, sosial dan budaya mereka sendiri dan juga tentang nilai-nilai orang lain. Mereka mempertanyakannya, memikirkannya, dan memilih apa yang akan dilakukan. Mereka belajar bagaimana menjadi orang bermoral yang bertanggungjawab yang tidak hanya melakukan hal-hal baik tetapi tahu mengapa dan bagaimana bertindak.

Dongeng Antik "Sayang Teman" juga memiliki beberapa kelemahan, antar alain: 1) Dongeng Antik "Sayang Teman" hanya dapat digunakan oleh kelompok kecil dengan jarak pandang yang sangat dekat. Hal ini dikarenakan ukuran buku dongeng hanya seukuran A4;2) Cerita yang disajikan hanya berupa cerita pendek, hal ini menjadikan buka tidak terlalu tebal.

Hal lain yang sangat mendukung dalam proses penelitian ini adalah penyajian dongeng. Meskipun anak-anak fokus meperhatikan buku dongeng, tetapi cara guru mendongeng, terutama suara dan intonasinya sangat membantu anak memahami pesan-pesan moral di dalam dongeng. Menurut Fitroh dan Sari (2015) dalam penelitiannya menyebutkan teknik yang baik bagi guru ketika mendongeng antara lain: 1) Baik dalam vokal, gerak dan komunikasi harus penuh ekspresi; 2) Mengondisikan anak supaya tertib; 3) dalam pembukaan cerita, membuat kesan pertama yang menggoda, sehingga membuat anak merasa penasaran; 4) menutup cerita dengan evaluasi atau tanyak jawab sederhana kepada anak; 5) tuturkan apa yang dapat diambil nilai dan makna cerita pada anak agar dapat ditanamkan dalam kehidupan sehari-hari.

\section{Kesimpulan}

Dongeng Antik berjudul "Sayang Teman" efektif untuk mengenalkan nilai moral bagi anak. Salah satu faktor yang mendukung kefektifan Dongeng Antik "Sayang Teman" ini adalah bentuknya yang berupa pop-up memudahkan anak memahami peristiwa di dalam cerita, sehingga anak memperoleh gambaran yang konkrit tentang sikap moral positif untuk mencegah kekerasan. Bahkan sebagian anak mampu menggambarkan contoh perilaku serupa dengan pengalaman sehari-hari. Hal tersebut menunjukkan bahwa anak memahami pesan moral yang terkandung di dalam Dongeng Antik "Sayang Teman".

Dongeng Antik "Sayang Teman juga memiliki kelemahan, yaitu hanya dapat digunakan dalam kelompok kecil dengan jarak pandang yang dekat, dikarenakan buku yang hanya berukuran A4. Selain itu, bentuk kekerasan yang dibahas dan nilai-nilai moral yang disampaikan juga terbatas. Maka dari itu, dibutuhkan bantuan guru dan orang tua untuk mencegah kekerasan sekaligus mengenalkan nilai-nilai moral kepada anak usia dini melalui 
pembiasaan sehari-hari. Peneliti merekomendasikan kepada guru dan orang tua agar mau menjadi pendengar dan teman yang baik bagi anak-anak, sehingga mereka lebih terbuka dan merasa dihargai.

\section{Daftar Pustaka}

Asri, B., (2004). Karakteristik siswa. Bahan Ajar Kuliah. Yogyakarta: Fakultas Ilmu Pendidikan UniversitasNegeri Yogyakarta.

Abbasi, M.A., Saeidi, M., Khademi, G., Hoseini, B. L., \& Moghada, Z. E. (2015). Child Maltreatment in The Worldwide: A Review Article. International Journal Pediatrics. Vol.3, N.1-1, Serial No.13: 353-365

Ahyani, L. N. (2010). Metode Dongeng dalam Meningkatkan Perkembangan Kecerdasan Moral Anak Usia Prasekolah . Jurnal Psikologi Universitas Muria Kudus, 1(1): 24-32

Al-Somadi, M. M. F. (2012). The Effect of A Story - Based Programme on Developing Moral Values at The Kindergarten Stage . Interdisciplinary Journal of Contemporary Research In Business, 4 (7): 534-559.

Ananda, R. (2017). Implementasi Nilai-Nilai Moral dan Agama pada Anak Usia Dini. Jurnal Pendidikan Anak Usia Dini, 1: 19-31.

Fitriyah, F. K. (2017). Reducing Aggressive Behavior Using Solution-Focused Brief Counseling $(S F B C)$. JBKI (Jurnal Bimbingan Konseling Indonesia), 2(2): 34-39. https://doi.org/http://dx.doi.org/10.26737/jbki.v2i2.254

Fitriyah, F. K. (2019). Pengaruh Perilaku Agresif pada Anak Usia Dini terhadap Kecemasan dan Empati. Education and Human Development Journal, 3(1): 96-102. https://doi.org/https://doi.org/10.33086/ehdj.v4i1.1088

Fitriyah, F. K., \& Purwoko, B. (2018). Youth narcissistic and aggression: A challenge for guidance and counseling service in University. Proceedings of The $1^{\text {st }}$ International Conference on Education Innovation (ICEI 2017): 109-111. https://doi.org/10.2991/icei17.2018.29

Purwoko, B., \& Fitriyah, F. K. (2018). Anger Management in Adolescents Behind Romantic Breakup: Implementation of Solution-Focused Brief Therapy. Proceedings of The $1^{\text {st }}$ International Conference on Education Innovation (ICEI 2017): 47-50. https://doi.org/10.2991/icei-17.2018.13

Fitroh, S. F., \& Sari, E. D. N. (2015). Dongeng sebagai Media Penanaman Karakter pada Anak Usia Dini. Jurnal PG PAUD Trunojoyo, 2(2): 76-149.

Habsy, B. A., Hidayah, N., Lasan, B. B., Muslihati, M., \& Fudholi, A. (2019). The Development Model of Semar Counselling to Improve the Self-Esteem of Vocational Students with Psychological Distress. International Journal of Emerging Technologies in Learning (iJET), 14(10): 132-149.

Lansdown, G. (2011). Every Child's Right To Be Heard (Resource Guide On the UN Committee On The Right of The Child General Comment No. 12. United Kingdom: Save the Children UK

Mursid. (2015). Belajar dan Pembelajaran PAUD. Bandung: PT Remaja Rosdakarya.

Rahim, H., \& Rahiem, M. D. H. (2012). The Use of Stories as Moral Education for Young Children. International Journal of Social Science and Humanity, 2(6): 454-458. 
Safitri, M. (2019). Selama 2019, KPAI Terima Kausus Kekerasan Anak. online. https://jabar.idntimes.com/news/indonesia/marisa-safitri-2/kpai-kekerasan-anak-palingbanyak-terjadi-dalam-pengasuhan-regional-jabar/full/ diakses tanggal 31 Desember 2019.

Saputri, E., Y., \& Astuti, H. P. (2019). Psychological Violence on Early Age Children Reviewed from Family Type in Welahan Village, Jepara Regency. Early Childhood Education Papers, 8(1): 1-6.

Santrock, J. W. (2011). Perkembangan Masa Hidup. Jakarta: Erlangga.

Sesmiarni, Z. (2019). The Effective Moral Education On Early Childhood As An Effort Against Immoral Culture . Jurnal Obsesi: Jurnal Pendidikan Anak Usia Dini, 3(2): 561-569.

Soetjiningsih, C. H. (2014). Perkembangan Anak: Sejak pembuahan sampai dengan kanakkanak akhir. Jakarta: Prenada.

Sugijokanto, S. (2014). Cegah Kekerasan pada Anak. Jakarta: PT Elex Media Komputindo.

Sugiyono. (2015). Metode Penelitian dan Pengembangan (Research and Development/ R\&D). Bandung: Alfabeta.

Susanto, A. (2014). Perkembangan Anak Usia Dini. Jakarta: Kencana.

Yuniati, A., Suyahmo., \& Juhadi. (2017). Perilaku Menyimpang dan Tindak Kekerasan Siswa SMP di Kota Pekalongan. Journal of Educational Social Studies (JESS), 1: 1-6. 